\title{
Analisis Pengaruh Rasio Keuangan Terhadap Penerimaan Opini Audit Going Concern
}

\author{
Deta Pransiska $^{1}$, Aminah $^{2}$ \\ Fakultas Ekonomi dan Bisnis, Universitas Bandar Lampung \\ Jl. Sukardi Hamdani, Lanuhan Ratu, Kedaton, 35142, Bandar Lampung, Indonesia \\ Email: \\ detapransiska30@gmail.com \\ aminah@ubl.ac.id
}

\begin{abstract}
ABSTRAK
Seorang auditor bertanggungjawab memberikan peringatan maupun sanksi kepada para pengguna laporan keuangan dalam mempertahankan going concern dimasa yang akan datang yang diatur dalam Pernyataan Standar Akuntansi. Penelitian ini digunakan untuk melihat pengaruh dari rasio likuidity, solvenvy, aktivity dan laverage terhadap penerimaan opini audit going concern. Manufacturing company yang tedaftar di Bursa Efek Indonesia pada tahun 2017-2019 merupakan populasi dalam penelitian ini. Metode purposive sampling merupakan sampel yang digunakan dalam penelitian ini. Jumlah sampel yang digunakan dalam penelitian ini sebanyak 69 perusahaan. Analisis statistik deskriftif dan analisis regresi logistik merupakan teknik analisis yang digunakan dalam penelitian ini. Hasil penelitian ini mengemukakan bahwa rasio aktivitytidakberpengaruh terhadap penerimaan opini audit going concern, sedangkan rasio likuidity, solvency dan leverage berpengaruh terhadap penerimaan opini audit going concern.
\end{abstract}

Kata Kunci : Opini audit going concern; rasio likuiditas; rasio solvency; rasio aktivity; rasio leverage.

\section{PENDAHULUAN}

Di Indonesia perusahaan yang berkembang di era globalisasi saat ini diharuskan mampu bersaing dan mempertahankan going concern dimasa yang akan datang. Dimana faktor-faktor yang mempengaruhi kelangsungan hidup suatu usaha dilihat dari finansial maupun nonfinansial. Going concern merupakan perkiraan sementara mengenai penyusunan laporan keuangan dimana perusahaan tersebut tidak berkeinginan untuk membubarkan usahanya mapun mengurangi secara materiil usahanya yang terdapat dalam pernyataan standar akuntansi (IAI, 2009; 5). Ada empat rasio keuangan yaitu rasio likuidity, rasio solvency, rasio aktivitity, dan rasio leverage. Dimana ke empat rasio tersebut merupakan bagian dari rasio keuangan yang bermanfaat bagi para pengguna laporan keuangan untuk mempertahankan kelangsungan usahanya dimasa yang akan datang (Diana, 2019). Standar Profesi Akuntansi Publik SA Seksi 341 paragraf 2 (IAPI, 2011) menjelaskan bahwa kelangsungan suatu usaha merupakan kemampuan suatu entitas dalam mempertahankan mempertahankan kelangsungan usahanyaapada waktu yang telah ditetapkan, yaitu kurang dari satu periode pada saat financial statementsdi audit. 
Fenomena yang terjadi adalah penghapusan pencatatan saham pada PT. Sekawan Intipratama Tbk oleh Bursa Efek Indonesia. Dimana Bursa Efek Indonesia menjelaskan bahwa pada peraturan No. 1-1 tentang penghapusan pencatatan atas saham PT. Sekawan Intipratama Tbk yang disebabkan karena going concern dalam perusahaan PT. Sekawan Intipratama mengalami kondisi yang secara signifikan berdampak buruk bagi perusahaan dimasa yang akan datang. Sehingga pada tangga 16 Juni 2019 Bursa Efek Indonisia medelestingpencatatan terhadap saham PT. Sekawan Intiparatama Tbk (Idxchannel.okezone.com, 2019).Penelitian ini ialah penelitian replikasi yang bermanfaat untuk mengetahui kembali pengaruh dari variabel yang telah diuji serta menggunakan sampel penelitian yang berbeda dan tahun yang terbaru. Berdasarkan uraian diatas penulis bermaksud untuk meneliti kembali pengaruh rasio keuangan terhadap penerimaan opini yang diberikan audit tentanggoing concern.Rumusan masalah dalam penelitian ini adalah apakah rasio likuiditas, rasio solvency, rasio aktivity dan rasio leverage memiliki pengaruh terhadap opini audit going concern. Tujuan penelitian ini untuk mengetahui pengaruh dari rasio likuidity, rasio solvency, rasio aktivity, dan rasio leverage terhadap opini yang diberikan audit tentanggoing concernsuatu entitas.

\section{TINJAUAN PUSTAKA}

Januarti (2009) Teori Agensi (Agency Theory)merupakan suatu perjanjian antara manajemen dan pemilik. Pemilik memberikan tanggungjawab kapada manager untuk mengelolaoperasional suatu entitas, dengan demikian informasi yang didapatkan oleh agen lebih banyak di bandingkan pemilik. Dalam hal ini pemilik menginginkan agar agen mengikuti perintah pemilik, namun terkadang agen lebih mementingkan kepentingan pribadinya sehingga terjadi manipulasi laporan keuangan dalam perusahaan. Dari pernyataan diatas, maka diperlukan pihak ke-3 yang independen dan kompeten dalam hal ini maka diperlukan auditor, karena tugas seorang auditor yaitu memberikan jasa penilaian terhadap kinerja yang dilakukan oleh agen dan opini audit sebagai hasil akhirnya.Jam'an (2008)menyatakan bahwa teori sinyal merupakan teori yang menjelaskan bahwa bagaimana suatu entitas memberikan informasi kepada kliennya. Teori sinya merupakan informasi yang dikeluarkan oleh perusahaan yang berguna bagi pihak stakholder yaitu laporan keuangan.Teori sinyal menyatakan bahwa suatu entitas akan memilih seorang audit terbaik untuk menunjukkan skill mereka dalam bekerja (Komalasari, 2004). Auditor memberikan opini audit terhadap pihak investor dan kreditor guna untuk mengetahui kelangsungan hidup suatu usahanya serta diharapkan mampu memberikan informasi bagi para pengguna laporan keuangan yaitu pihak kreditor maupun investor, sehingga mampu memperkirakan secara sistematis kemampuan perusahaan dimasa yang akan datang.

Mulyadi (2013: 9) auditing ialah suatu metode yang mampu menjelaskan serta bisa memberikan bukti yang akurat mengenai kondisi keuangan dalam perusahaan dengan tujuan mampu memberikan penjelasan antara pernyataan dengan prestasi kerja yang telah ditentukan, sehingga dapat memberikan iinformasi atas hasil yang telah didapat kepada pihak internal maupun eksternal.Daniel dan Mihaela (2018) menyatakan bahwa ketidakpastian tentang kelangsungan suatu usaha akan membuat perusahaan bangkrut. SPAP (2001) Menjelaskan bahwa going concernadalah seberapa mampu suatu entitas dalam mempertahankan kelangsungan hidup usahanya pada waktu yang telah ditetapkan, yaitu perusahaan harus menyampakai laporan keuangan tidak lebih dari satu periode pada saat akan diaudit. Menurut Baridwan (2011: 8) Going concern yaitu suatu entitas yang mampu mempertahankan keberlangsungan usahanya dimasa yang akan datang. Pernyataan ini menjelaskan bahwa apabila suatu entitas tersebut mampu mempertahankan going concrn maka perusahaan tersebut mampu memenuhi perekonomiannya dimasa yang akan datang 
serta perusahaan tersebut bisa dikatakan mampu melakukan operasional dan melanjutkan usahanya tanpa adanya keraguan going concern pada perusahaan dimasa yang akan datang. Sedangkan Opini audit going concenmerupakan kelangsungan suatu entitas dimana perusahaan tersebut mampu mempertahankan bisnisnya dimasa yang akan datang. Opini audit going concrn merupakan opini yang dikemukakan seoarang audit yang menjelaskan bahwa suatu entitas yang manpu memertahankan going concernuntuk periode selanjutnya, serta telah di atur oleh PSA 29 paragraf 11 yang menjelaskan tentang keraguan yang tinggi terhadap skill perusahaan untuk mempertahankan going concern dimasa yang akan datang. Pada suatu kondisi seorang akuntan publik diharuskan menambahkan paragraf penjelas pada laporan keuangan perusahaan yang telah diaudit meskipun paragraf penjelas tersebut tidak memiliki pengaruh terhadap pernyataan tentang pendapat wajar tanpa pengecualian (Ernita, 2018).

Rasio keuangan yaitu rasio yang mendeskrifsikan tentang keterkaitan atarasejumlah akun terhadap akun lainnya yang terdapat dalam financial statements. Dimana penilaian kinerja yang diterima oleh manajer dalam perusahaan tersebut dapat dilihat dari nominal yang ada pada financial statements suatu entitas (Diana, 2018). Diana (2018) menyatakan bahwa rasio terbagi menjadi empat, yaitu, rasio likuidotas, rasio solvabilitas (leverage), rasio aktivitas (aktivity ratio) dan yang terakhir yaitu rasio profitabiltas (rentabilitas).

Rasio LikuiditasRasio ini menjelaskan bahwa seberapa mampu perasahaan dalam membiayai kewajiban keuangan dalam perusahaan pada saat jatuh tempo. Dapat diasumsikan bahwa jika perusahaan tersebut sudah mampu membiayai hutang maka perusahaan tersebut merupakan perusahaan yang baik. Pengukuran yang biasa dipakai dalam menghitung rasio likuidity yaitu: Rasio lancar (Current Ratio)memberikan penjelaskan dimana rasio tersebut menilai kemampuan suatu usaha dalam membayar hutang nya menggunakan aktiva lancar pada saat jatuh tempo. Rumus yang dipakai rasio lancar yaitu:

$$
\text { Current Ratio }=\frac{\text { Current Asset }}{\text { Current Liabilities }}
$$

Diana (2018) Rasio solvabilitas (leverage) menjelaskan bahwa untuk menilai rasio tersebut dilihat dari seberapa mampu perusahaan dalam membiayai hutang nya baik pada saat jatuh tempo mapun pada saat jangka panjang. Perusahan yang mampu membiayai hutangnya pada saat jatuh tempo mapun jangka panjang belum tentu likuid, begitu juga sebaliknya. Gharaghayah (2013) menyatakan bahwa jika rasio solvabilitas merupakan rasio yang paling penting menurut pejabat audit dalam memperluas perusahaan. Pengukuran yang digunakan rasio silvabilitas (leverage) ialah: Total debt to asset ratio adalah rasio yang menilai kemampuan suatu usaha dalam membiayai hutangnya dengan sejumlah assets yang dimilikinya. Rumus yang digunakan untuk menghitung total debt to asets ratio adalah:

Total debt to asset ratio $=\frac{\text { Total Liability }}{\text { Total Assets }}$ X 100\%

Diana (2018) Rasio aktivitas menjelaskan bahwa dimana rasio tersebut digunakan untuk menilai seberapa mampu perusahaan dalam menggunakan aktva serta sumberdaya yang dimilikinya. Pengukuran yang digunakan rasio aktivitas (aktivity ratio) adalah: Perputaran total aset pada rasio ini digunakan untuk menilai tingka perubahan total aset terhadap sales dalam perusahaan. Rumus yang digunakan perputaran total assets ialah:

Perputaran total asset $=\frac{\text { Penjualan bersih }}{\text { Rata-rata total aset }}$

Diana (2018) Rasio profitability merupakan rasio yang berguna bagi perusahaan dalam menilai kemampaun suatu usaha untuk mendapatkan keuntungan yang didapat dari 
sales, assets dan equity dalam perusahan. Rasio profitabilitas menjelaskan bahwa seberapa mampu perusahaan dalam memperoleh keuntungan. Saladrigues (2016) menyatakan bahwa semakin positif ROA maka semakin rendah profitabilitas perusahaan dalam menerima opini audit going concern. Pengukuran yang digunakan rasio profitability adalah:Tingkat pengembalian aset pada rasio ini berguna untuk mengetahui kemampuan suatu entitydalam memperoleh keuntungan dengan keseluruhan aktiva yang dimiliki oleh perusahaan tersebut. Dapat asumsikan bahwa semakin besar tingkat pengembalian aset maka semakin baik operasional dalam persahaan tersebut. Rumus yang digunakan oleh tingkat pengembalian aset ini adalah:

Tingkat pengembalian aset $=\frac{\text { EBIT }}{\text { Total aset }} \times 100 \%$

\section{METODE PENELITIAN}

Dalam penelitian ini jenis penelitian yang digunakan ialah penelitian kuantitatif, data yang diambil dalam penelitian inifinancial statementstahunan yang terdapat pada manufacturecompany yang tercatat di Bursa Efek Indonesiia periode 2017-2019.Populasi dalam penelitian ini menggunakan datamanufacture companyyang berjumlah 176 prusahaan yang tercatat di Bursa Efek Indinesia pada tahun 2017-2019. Purposive sampling merupakan metode yang digunakan dalam penelitian ini. Kriteria sampelyang dipilihdalam penelitian ini ialah:

1. Manufacture companypada tahun 2017-2019 yang tercatat di Bursa Efek Indoneisia.

2. Manufacture company yang menyediakan financial statementsyang menggunakan mata uang rupiah (RP).

3. Manufakturing companyyang dihapuskan pencatatannya oleh Bursa Efek Indonesia pada tahun 2017-2019.

4. Manufacturing company pada tahun 2017-2019 yang mengeluarkan laporan auditan serta dalam perusahaan tersebut terdapat laporan yang independen.

5. Perusahaan manufaktur yang memiliki keuntungan bersih setelah pajak yang bernilai negatif selama tiga tahun yaitu dari tahun 2017-2019.

Penelitian ini menggunakan data sekunder. Data yang digunakan diambil dari www.saham.com serta sumbernya dariwww.idx.co.id. Dalam penelitiian ini dokumentasi merupakan data yang dipakai oleh peneliti. Sedangkan variabel dalam penelitian menggunakan dependen variable dan independent, dimana dependen variableyang digunakan dalam penelitian ini yaitu opini yang diberikan audit tentanggoing concern. sedangkan variable independent yang digunakan dalam penelitian ini adalah rasio likuidity, rasio solvency, rasio aktivity, dan rasio leverage.

Analisis statistic deskriftif adalah analisis yang berfungsi untuk mengetahui ciri-ciri sample yang digunakan dan mendeskripsikan antara dependen variabledengan independent variabledalam penelitian ini. Selanjutnya analisis statistik deskriptif ini bertujuan untuk mengetahui nilai minimum, maximum, mean dan stand deviasi dari variabel dependen maupun independen. sedangkan uji asumsi klasik dalam penelitian ini menggunakan analisis regresi logistik untuk menguji data dalam penelitian ini dimana variabel yang digunakan dalam penelitian ini merupakan variabel angka. Analisis regreai logistik dalam penelitian ini berfungsi untuk melihat pengaruh dari rasio likuiditas, slvability, aktivity, dan leverage terhadap penerimaan opini yang diberikan audit tentang going concern.Penelitian ini 
menggunakan logistic regression model sebagai uji asumsi kalsiknya, berikut model regresi logisntiknya:

$Y=\alpha+\beta_{1}\left(X_{1}\right)+\beta_{2}\left(X_{2}\right)+\beta_{3}\left(X_{3}\right)+\beta_{4}\left(X_{4}\right)+e$

\section{PEMBAHASAN DAN HASIL PENELITIAN}

Penelitian inii menggunakan data sekunder. Data digunakan dalam penelitian diambil dari manufacturing compnyyang terdaftar di Bursa Efek Indonesia dan bersumber dari www.idx.co.id. Purposive sampling merupakan metode yang digunakan dalam penelitian ini. Berikut ini kriteria sampel yang dipilih oleh peneliti:

Tabel 1. Prosedur Penarikan Sample

\begin{tabular}{llc}
\hline No & \multicolumn{1}{c}{ Keterangan } & Tahun penelitian 2017-2019 \\
\hline 1. & Manufacturing companypada tahun 2017-2019 & 176 \\
yang tercatat di Bursa Efek Indonesia. & \\
2. & Financial statementsyang tidak diterbitkan serta \\
telah diaudit oleh perusahaan pada tahun 2017- & \\
2019. & \\
3. Manufakturing company yang delisting pada tahun & $(5)$ \\
2017-2019. & Financial statements yang telah diaudit yang \\
mempunya laba negatif selama 2 periode yang \\
terdapat di manufacturing company dan tercatat di \\
Bursa Efek Indionesia.
\end{tabular}

Sumber : Hasil Olah Data 2021

Analisis statistik deskriptif digunakan untuk mengetahui variabel dari rasio likuidity, solvency, aktivity, leverage dan opini yang diberikan oleh auditor tentanggoing concern. Dalam penelitian ini nilai rata-rata, nilai median, nilai modus, dan niali standar deviasi merupakan pengukuran untuk analisis statistik deskriptif. Pengelolaan data untuk analisis statistik deskriptif ini menggunakan SPSS 18. Dibawah ini hasil dari analsisi statistik deskriftif.

Tabel 2. Analisis Statistick Deskriptif

\begin{tabular}{lccccc}
\hline \multicolumn{1}{c}{ Variabel } & $\mathrm{N}$ & Minimum & Maximum & Mean & Std. Deviation \\
\hline Rasio Likuiditas & 69 & .027 & 6.878 & 1.81168 & 1.259471 \\
Rasio Solvabilitas & 69 & .065 & 2.183 & .71533 & .543259 \\
Rasio Aktivitas & 69 & .007 & 3.321 & .76157 & .592837 \\
Rasio Profitabilitas & 69 & -1.369 & 1.199 & -.09161 & .443438 \\
Opini Audit Going & 69 & 0 & 1 & .17 & .382 \\
Concern & & & & & \\
Valid N (Listwise) & 69 & & & &
\end{tabular}

Sumber : Hail Olah Data SPSS 2021

Rasio likuiditas diukur menggunakan curretn asset dimana rasio ini digunakan untuk mengukur seberapa mampu suatu entitas dalam memenuh kewajiban jangka pendeknya. Hasil 
data yang diperoleh dari statistik deskriptif yang dilakukan dimana nilai miniimumnya 0,027 terdapat pada PT. Asahimas Flad Glass Tbk tahun 2019, dan nilai maksimumnya di peroleh sebesar 6,878 yang terdapat pada PT Inti Agri Resources Tbk tahun 2017. Sedangkan untuk nilai mean yang memperoleh nilai sebesar 1,81168 dan standar deviasinya sebesar 1.259471.Rasio solvabilitas diukur menggunakan total debt to asets ratio dimana rasio digunakan untuk mengukur seberapa mampu suat entitas dalam memenuhi financialjangka panjangnya. Berdasarkan hasil data statistik deskriptif yang dilakukan, doperoleh nilai minimum sebesar 0.065 pada PT Inti Agri Resouerces Tbk tahun 2019 dan nilai maksimumnya sebesar 2.18 pada PT Magna Investaa Mnadiri Tbk tahun 2019. Sedangkan nilai mean yang diperole sebesar 0.71533 dan standar deviasinya diperoleh nilai sebesar 0,543259. Rasio aktivity diukur dengantotal aset turn over dimana rasio digunakan untuk mengukur seberapa mampu suatu entitas dalam mengatur sumber daya dan aktiva yang dimiliki. Berdasarkan hasil statistick deskriptif yang dilakukan sehingga memperoleh nilai minmum sebesar 0.007 pada PT Inti Agri Resouurces Tbk pada tahun 2018 dan nilai maksimumnya diperoleh sebesar 3,321 terdapat pada PT Asia Pasipik Invesatama Tbk pada tahun 2019. Nilai rata-ratadiperoleh sebesar 0,76157 dan standar deviasinya diperoleh nilai sebesar 0,592837. Rasio profitabilitas diukur dengan return on assets dimana rasio ini digunakan untuk mengukur seberapa mampu entitas dalam menghasilkan keuntungan. Berdasarkan data statistik deskriftif yang dilakukan, doiperoleh nilai minimum sebesar -1,369 terdapat pada PT. Magna Investama Mandiri Tbk dan nilai maksimumnya diperoleh sebesar 1.199 terdapat pada PT MarkDynamick Indonesia Tbk. Sedangkan nilai mean yang diperoleh -0,09161 dan standar deviasinya diperoleh nilai sebesar 0,443438. Opini yang diberikan audit tentang going concern diukur mennggunakan variabel dummy, dimana entitas yang menerima opini audit going concer diberi angka 1 dan entitas yang tidak mendapat opini audit going concern di beri angka 0 . Berdasarkan data analisis statistik deskriptif yang dilakukan maka diperoleh nilai min sebesar 0 dan max diperoleh niali sebesar 1 . Sedangkan mean diperoleh nilai 0,17 dan nilai standar deviasinya diperoleh sebesar 0,382 .

Dalam penelitin ini sebelum melakukan pengujian hipotesis maka terlebih dahulu dilakukan uji normalittas, uji multikolinieritas, dan uji heterokedasitis. Dimana uji normalitas berfungsi untuk melihat apakah data yang diuji normal atau tidak. Uji ini dilakukan dengan uji kolmogrov smirnov, dari uji ini dapat diketahui bahwa jika data yang diuji normal dilihat dari asymp sig (2-tailed), yaitu melihat perbandingan antara profitabilitas yang diperoleh dengan taraf sig nya yaitu 0,05 . Selanjutnya uji multikolinieritas berfungsi untuk mengetahui tela $\mathrm{h}$ terjadi kesamaan antara korelasi dengan variabel indevemden, dimana jika model regresi tersebut tidak terjadi kesamaan antara korelasi dengan variabel nya maka model tersebut baik. Adapun unutk melihat apakah uji multikolinieritas dikatakan baik isa dilihat dari Tolerance dan VIF dimana jika tolerancediatas 0,01 dan VIF nya dibawah 10,0 yang memiliki arti bahwa data tersebut tidak terjadi multikol. Yang terakhir yaitu uji heteroskedastisitas yang menjelaskan bahwa jika dasar pengambilan keputusan ujinya melalui glejser apabila nilai signya di atas 0,05 . Dengan demikian jika uji signya diatas 0,05 maka tudak terjadi gejala heteroskedastisitas

Pengujuan secara parsial dalam penelitian digunakan untuk mengetahui pengaruh dari independent variable yaitu rasio likuidity, solvency,aktivity, dan leverage terhadap dependen variableyaitu penerimaan terhadap opini yang di berikan audit tentang going concern. dimana dalam penelitian ini analisis untuk menguji datanya menggunakan model regresi logistik.Berdasarkan hasil uji secara parsial yang menggunakan model tregresi logistik dapat diberi kesimpulan sebagai

berikut: 
$\mathrm{Y}=-9,098+1,020 \mathrm{CA}+5,020 \mathrm{TDA}+0,828 \mathrm{TAT}-2,344 \mathrm{ROA}+\mathrm{e}$

\section{PEMBAHASAN}

Pengujian secara parsial terhadap rasio likuiditas, dapat disimpulkan bahwa nilai koefisien dari rasio likuiditas mendapat nilai sebesar 1,020 yang mengemukakan bahwa rasio likuidityberpengaruh posotifterhadap penerimaan opini auditeegoing concer. Selanjutnya dapat kita lihat nilai signifikan yang di dapat dari hasil uji terdapat nilai sebesar 0,043 dan kurang dari 0,05 pada rasio likuidity, artinya rasio likuidity dalam penelitian ini $\mathrm{H}_{1}$ nya diterima. Sehingga dapat simpulkan bahwa rasio likuiditas memiliki pengaruh positif terhadap penerimaan opinii auditegoing concern yang terdapat pada manufacturing company yang tercatat di Bursa Efek Indonesia tahun 2017-2019.Penelitian ini menetapkan hasil bahwa apabila rasio likuiditas dalam entitasmengalami penurunan maka suatu entitas tersebut akan lebih tinggi mendapatkan opini yang dikeluarkan oleh auditor tentang keraguan suatu entitas dalam mempertahankan kelanggsungan hidupnya dimasa yang akan datang. Serta auditor juga akan melihat dari kemampuan entitas dalam membiayai kewajiban finansialnya tepat waktu. Sehingga jika suatu entitas mampu mimbiayai kewajiban financialnya tepat waktu maka perusahaan tersebut tidak akan menerima opini yang dikeluarkan oleh auditor tentang keraguan entitas dalam mempertahankan kelagsungan hidupnya dimasa yang akan datang, begitupun sebaliknya jika suatu entitas tidak mampu membiayai kewajiban financialnya tepat waktu maka perusahaan akan mendapat opini dari auditor tentang keraguan dalam mempertahankan kelangsungan usahanya dimasa yang akan datang.

Pengujian secara parsial terhadap rasio solvabilitas, dapat disimpilkan bahwa nilai koefisien dari rasio solvabilitas mendapatkan nilai sebesar 5,020 yang menyatakan bahwa rasio solvency berpengaruh positif terhadap peneriman opini auditegoing concen. selanjutnya dapat kita lihat nilai yang didapat dari hasil uji tersebut terdapat nilai sebesar 0,001 dan kurang dari 0,05 pada rasio solvabilitas, artinya rasio solvabilitas dalam penelitian ini $\mathrm{H}_{2}$ nya diterima. Sehingga dapat disimpulkan bahwa rasio solvency berpengaruh positif terhadap penerimaan opini auditeegoiing concern yang terdapat pada manufacturing company yang tercatat di Bursa Efek Indonesia tahun 2017-2019.Penelitian ini menetapkan hasil bahwa apabila rasio solvabilitas dalam perusahaan meningkat maka akan membuat perusahaan mendapatkan resiko yang lebih besar. Karena jika solvabilitas dalam perusahan meningkat maka auditor akan beranggapan bahwa perusahaan tersebut tidak mampu membiayai aset dalam perusahaan, dan lebih banyak didanai oleh peminjam. Apabila hutang dalam perusahan tinggi maka akan berdampakpada perusahaan dalam membiayai asetnya. Sehingga dalam kondisi ini auditor akan cenderung beranggapan bahwa entitas tersebut tidak mampu mempertahankan kelangsungan usahanya dimasa yang akan datang. Berdasarkan asumsi diatas maka dapat diartikan bahwa apabila rasio solvency semakin meningkat maka entitytersebut akan lebih besar mendapatkan opini dari auditor tentang kalangsungan suatu entitas dalam mempertahankan kelangsungan usahanya dimasa yang akan datang.

Pengujian secara parsial terhadap rasio aktivitas, dapat disimpulkan bahwa nilai koefisien dari rasio aktivitas mendapat niali sebesar 0,828 yang menyatakan bahwa rasio aktivitas tidak berpengaruh terhadap penerimaan opini audit going concern. selanjutnya dapat kita lihat nilai signifikan yang didapat dari hasil uji tersebut terdapat nilai sebesar 0,245 dan lebih dari 0,05 pada rasio aktivitas, asrtinya rasio aktivitas dalam penelitian ini $\mathrm{H}_{3}$ nya ditolak.Sehingga dapat disimpullkan bahwa rasio aktivitas tidak berpengaruh terhadap penerimaan opini audit going concern yang terdapat pada manufacturing companyyang tercatat di Bursa Efek Indonesia tahun 2017-2019.Penelitiian ini menetapkan hasil bahwa rasio aktivitas dalam perusahaan dilihat dari total aktiva yaitu seberapa mampu perusahaan 
dalam memperoleh pendapatan atas penjualan. Perusahaan manufaktur pada umumnya akan mengalami kondisi fluktuasi dimana total aktiva dalam perusahaan tersebut mengalami penurunan sehingga perusahaan cenderung akan mendapat opini yang dikeluarkan oleh auditeetentang keraguan suatu entitas dalam mempertahankan kelangsungan usahanya dimasa yang akan datang.

Pengujian secara parsial terhadap rasio profitabilitas, dapat disimpuilkan bahwa nilai koefisien dari rasio profitabilitas mendapat nilai sebesar -2,344 yang menyatakan bahwa rasio profitabilitas berpengaruh terhadap peneriman opini auditegoing concern. Selanjutnya dapat kita lihat nilai signifikan yang di dapat dari hasil uji tersebut terdapat nilai sebesar 0,047 dan kurang dari 0,05 pada rasio leverage, artinya rasio leveragedalam penelitian ini $\mathrm{H}_{4}$ nya diterima. Sehingga dapat diasumsikan bahwa rasio profitabilitas berpengaruh terhadap penerimaan opini audit going concern yang terdapat pada manufacturing companyyang tercatat di Bursa Efek Indonesia tahun 2017-2019.Penelitian ini menetapkan hasil bahwa semakin besar rasio leveragedalam suatu entitas maka semakin tinggi entitas tersebut dalam memperoleh keuntungan. Sehingga jika perusahaan yang memiliki rasio leverageyang besar maka seorang audit akan berasumsi bahwa perusahaan tersebut mampu membiaya semua kewajiban nya pada waktu jangka pendek maupun jangka panjang, kemudian suatu entitas akan dianggap mampu mempertaahankan keberlangsungan usahanya dimasa yang akan datang.

\section{KESIMPULAN DAN SARAN}

Rasio likuidityberpengaruh positif terhadap penerimaan opini auditegoing concen, yang menjelaskan bahwa apabila rasio likuidity dalam suatu entitas terjadi penurunan makaentitas tersebut akan lebih tinggi mendapatkan opini yang diberikan auditor tentang keraguan suatu entitas dalam mempertahankan kelangsungan usahanya dimasa yang akan datang.Rasio solvabilitas memiliki pengaruh positif dan signifikan teradap penerimaan opini auditeegoing concern, yang menjelaskan bahwa apabila rasio profitabilitas semakin meningkat maka perusahaan tersebut akan lebih besar mendapatkan opini dari auditor tentang kelangsungan suatu entitas dalam mempertahankan usahanya dimasa yang akan datang. Rasio Aktivity tidak memiliki pengaruh terhadap penerimaan opini audit going concern, yang berarti rasio aktivitydalam persahaan dilihat dari total aktiva yaitu seberapa mampu perusahaan dalam memperoleh pendapatan atas penjualan. Perusahaan manufaktur pada umumnya akan mengalami kondisi fluktuasi dimana total aktiva dalam perusahan akan menurun sehingga perusahaan cenderung akan mendapat opini yang diberikanaudit tentang going concernn dimasa yang akan datang.Rasio profitabilitas berpengaruh terhadap penerimaan opini audit going concern, yang berarti semakin besar rasio profitabilitas dalam suatu entitas maka semakin tinggi entitas tersebut dalam memperoleh keuntungan, serta auditor beranggapan bahwa perusahaan tersebut mampu mempertahankan kelangsungan hidupnya.

Diharapkan untuk penelitian selanjutnya memakai pengukuran yang lain, seperti rasio profitabilitas hanya menggunakan alat ukur ROA maka diharapkan penelitian selanjutnya bisa menggunakan alat ukur lain nya yaitu ROI dan ROE. Serta diharapkan mampu menambahkan jumlah data entitas yang menjadi sampel penelitian dan yang terakhir diharapkan mampu menambahkan jumlah periode dala penelitian nya.

\section{DAFTAR PUSTAKA}

Baridwan, Zaki. (2011). Intermedite Acounting, Edisi Kedelapan. Cetakan Keempat. Yogyakarta. 
Daniela, H.C., And Mihaela, I.C. (2018). Auditor's Uncertainty About Going ConcernPredictor of Insolvency Risk. "Ovidius" Uneversitas Annal, Ecconomic Sciences Series Volume XVIII. Issue 2.

Diana, S.R. (2018). Analisis Laporan Keuangan dengan Aplikasinya. Cetakan Pertama. Bogor : In Media.

Ernita, Sri. (2018). Analisis Pengaruh Kalitas Auditor, Likuiditas, Profitabilitas, Silvabilitas, dan Pertumbuhan Perusahaan terhadap Opini Audit Going Concrn pada perusahaan Manufaktur yang Terdaftar di Bursa Efek Indonesia. JON FEB. Vol.1, Edisi 1 (Januari-Juni 2018). Universitas Riau. Pekanbaru.

Gallizo, J.L., and Saladrigues, R. (2016). An Analysis of Determinants of Going Concern Audit Opinion: EvidenceFrom Spain Stock Exchange. Universitas De Lieida, Spain.

Gharaghayah, H.M., Jahanshad, A., Adhami, S. (2013). An Analysis of determinants $f$ going concern audit opinion: Evidence from Tehran Stock Exchange. School of Ecconomic and accounting, central Tehran Branch, Islamic Azad University (IAU), Tehran.

Idxchannel.Okezone.com. (2019). Delisting Saham PT. Sekawan IntipratamaTbk. Diambil dari hhtps://idxchannel.okezobe.com/read/2019/06/14/278/2066398/delisting-sahamsekawan-intipratama-simak-penjelas-bei.

Ikatan Akuntan Indonesia. (2001) Standart Profesional Akuntansi Publick. PSA 29 SA Seksi 508. Jakarta : Ikatan Akuntansi Indonesia.

Ikatan Akuntan Indonesia. (2009) Pernyataan Standar Akuntansi Keuangan. PSAK. Jakarta : Penerbit Selemba Empat.

Institut Akuntansi Publik Indonesia. (2011). Standart Profesional Akuntansi Publik. Jkarta: Selemba Empat.

Institut Akuntansi Publik Indonesia. (2013). Standart Auditing (SA) 570 Kelangsungan suatu usaha. Jakarta: Selemba Empat.

Jama'an. (2008). Pengaruh Mekanisme Corporate Governance, dan Kualitas Auditor Akuntansi Publik terhadap integrits Informassi Laporan Keuangan (Studipada Perusahaan Publik di BEI). Semarang : Universitas Diponogoro.

Januarti, Indira. (2009). Analisi pengaruh faktor peusahaan, kualitas auditor, kepemilikan Perusahaan tehadap penerimaan opini audit going concern (Perusahaan manufaktur yang terdaftar di BEI). In: Simposium Nasional Akuntansi 12. Palembang.

Komalasari, A. (2004). Analisis Pengaruh Kualitas Auditor dan Proxi going concern terhadap opini auditor. Jurnal Akuntansi Keuangan, 9(2), 1-15.

Komite SPAP Ikatan Akuntansi Indonesia, (2001). Standar Akuntansi Publik. Jakarta: Selemba Empat.

Mulyadi. (2013). Auditing. Buku Dua. Jakarta: Selemba Empat. 
Rizal, S., \& Permatasari, f. (2015). Pengaruh Kinerja Keuangan DER dan ROE terhadap Perusahaan Harga Saham pada Perusahaan Manufaktur yang Terdaftar di Bursa Efek Indonesia (Periode 2009-2013). Jurnal Akuntansi dan Keuangan, 6(2).

Tarmizi, R., SOEDARSO, H.G., INDRAYENTI, I., \& ADRIANTO, D. (2018). Pengaruh Likuiditas dan Provitabilitas terhadap Return Saham. Jurnal Akuntansi Keuangan. 2018, 9(1).13.

$\underline{\text { www.idx.co.id }}$

$\underline{\text { Www.sahamok.com }}$ 